Article

\title{
Contempt and Labour: An Exploration through Muslim Barbers of South Asia
}

\author{
Safwan Amir
}

Madras Institute of Development Studies, University of Madras, Chennai 600020, India; safwan.in@gmail.com

Received: 9 September 2019; Accepted: 4 November 2019; Published: 6 November 2019

check for updates

\begin{abstract}
This article explores historical shifts in the ways the Muslim barbers of South Asia are viewed and the intertwined ways they are conceptualised. Tracing various concepts, such as caste identity, and their multiple links to contempt, labour and Islamic ethical discourses and practices, this article demonstrates shifting meanings of these concepts and ways in which the Muslim barbers of Malabar (in southwest India) negotiate religious and social histories as well as status in everyday life. The aim was to link legal and social realms by considering how bodily comportment of barbers and pious Muslims intersect and diverge. Relying on ethnographic fieldwork among Muslim barbers of Malabar and their oral histories, it becomes apparent that status is negotiated in a fluid community where professional contempt, multiple attitudes about modernity and piety crosscut one another to inform local perceptions of themselves or others. This paper seeks to avoid the presentation of a teleology of past to present, binaries distinguishing professionals from quacks, and the pious from the scorned. The argument instead is that opposition between caste/caste-like practices and Islamic ethics is more complex than an essentialised dichotomy would convey.
\end{abstract}

Keywords: barber; Ossan; caste; Islam; contempt; labour; Mappila; Makti Thangal; Malabar; South Asia

\section{Introduction}

The modern nation-state of India has maintained an ambiguous relationship with caste and minority religions especially concerning reservation policies in various state and non-state sectors. There is minimal official government data on diverse populations among these religious categories given that larger discourses tend to follow an inter-religious (communal/secular) narrative rather than intra. The latter has, thankfully, been thoroughly examined by scholars. The literature on social stratification among Muslims in South Asia has predominantly focused on caste, occupation, status-groups, purity-pollution, marriage, kinship, and class. A central premise that unites these studies is that though Islam is an egalitarian religion in theory, everyday praxis suggests the contrary. Simultaneously, a linear history asserts the continuity of prior forms of caste ordering regardless of conversions to Islam from earlier religious systems in the region. While there is inadequate conceptual clarity between employing "caste" or "caste-like" as representing the phenomena, there is a consensus that certain sections of Muslims in South Asia are held in disdain. Within marriage and occupation, the highest manifest bands of this spectrum of contempt can be found. While the former can be claimed to be event-based in a person's lifetime, occupation-related labour directly enters the realm of everyday sociality. ${ }^{1}$

This article was an attempt to trace shifting meanings of contempt and labour in the histories and everyday lives of the Muslim barbers of Malabar (southwest Indian subcontinent). I begin by analysing

1 The idea is not to compare these two highly related aspects but to concentrate on one for the purposes of this article. 
the relation between quacks and professionals in post-independent India. The newly emergent nation's aspirations and anxieties can be captured through its ties with biopower. I work along with two professions-barbers and doctors - to complicate modern perceptions around occupation and labour. Next, I explore authority and Islam during the peak of colonialism in India. Connections between legal and social realms go through decisive adjustments that impact the moral. Additionally, we find bodily sensibilities and notions around piety undergoing major shifts during this transformative period. In this section, I compare the prayer bump to the barber's callus to navigate through body, memory and work. Finally, we probe into the barber's early labour by locating him during the advent of colonial power in India. This leads us to the terrain of possibilities within the Islamic tradition. Rather than thinking through a teleology of past to present, I place these dispersed temporalities in contradiction with one another to show the multifaceted interplay between power and ethics in South Asia. The larger aim was to argue that opposition between caste/caste-like practices and Islamic ethics is more complex than easy dichotomies and a mere Is and Ought distinction. Moreover, it tried to open up avenues in thinking about social stratification without falling for easily drawn models. This article is part of a larger historical anthropological project and draws on recent moral philosophical research, South Asian history, oral narratives, theology and ethnography carried out between the years 2014 and 2017.

Malabar, currently part of the state of Kerala in post-independent India, is famous for having received the first Muslims to the subcontinent. The Muslim community that flourished since then was named the Mappila, by the Arabs and later categorised into a singular unit by the colonial British administration. The general trend in studies around the Muslims of Malabar has been around the history of the Malabar Rebellion of 1921, historical origins and subaltern resistance. There is very little of how the past shapes the present in myriad ways. Exceptions are Punathil (2013), where he studies present-day marginalisation of the Mappilas as having roots in their colonial past and negative labelling as "fanatic"; Kasim (2018) takes a similar turn to examine the British colonial construction of modern Mappila masculinity; and Muneer (2016), where he explores the role of early devotional performance genres in cultivating a Mappila ethical self in the contemporary. The Muslim barber or Ossan (female Ossathi) ${ }^{2}$ is an integral part of most Muslim settlements in this region, and literature on stratification generally places them in the lowest rungs of the social ladder. This literature further divides the Mappila based on endogamy (usually high-status family groups like Thangal/Syed or Koya) and occupation (low-status groups that include Ossan and fisherfolk referred to as Pusalan) (Miller 1976; Kunju 1989; D'Souza 1959; D'Souza 1973). This conceptualisation follows the Ashraf-Ajlaf dichotomy, prevalent in North Indian academic discourses (Ahmad 1967; Nazir 1993), which builds on descent, birth, race and nobility, on the one hand, and village artisans and occupational status groups on the other, respectively. A significant influence of the Hindu ${ }^{3}$ caste system can be seen throughout most works on social stratification among Muslims in India. Regional versions can be found, but the four varna system has been the structural framework for most scholars even within these variations. In the South Indian setting, one study takes a different trajectory through the question of caste among Tamil Muslims and moves away from ahistorical, structuralist and functionalist approaches to posit historically, analysing the changing political and economic situations as the way forward, while also suggesting that the colonial invention of caste and the invention of Muslim stratification are related (Fanselow 1996). Though the colonial era proves to be decisive in shaping many of the discourses around caste and stratification, I believe internal actors and processes need to be accounted for as well. On a different note, the attempt while taking Malabar as illustrative of South Asia is to move beyond centre-periphery arguments, especially to challenge those that presume the North Indian case

2 I will refrain from using the terms Ossan and Ossathi as most interlocutors did not want to identify with these names and rather preferred to be known as barbers/beauticians or as hailing from barber families. They are known as Osta (derived from usthad/instructor) in the Sri Lankan setting (McGilvray 2008).

3 There is considerable debate around what "Hindu" and "Hinduism" implies. I refer to upper-caste traditions by the term. 
to be representative of everything that comes within the Indian subcontinent. Most of these studies on difference are based on North Indian experiences and models; and there is a lacuna in academic works from South Asia based on other experiences, especially from South India (Tschacher 2014). Further, the enquiry considers single ethnographic works or case studies of a single community as more effective than multi-centred or multi-caste studies that usually take the field to be secondary.

Contempt (puccham in Malayalam) in present-day South Asia is commonplace like various other societies. The related facial expression-“a tightening and slight raising of the lip corner, primarily on one side of the face" (Ekman and Heider 1988)—is easily identifiable in a Kerala setting as puccha bhavam. Slur words, denoting pubic hair, like myr (Malayalam, Tamil) and jhaant (Hindi) are frequent expressions within present vocabularies of contempt and make for daily exchanges and popular culture. The barber's intimate connection with hair has often been subject to ridicule against or around the profession. ${ }^{4}$ To look down on particular kinds of work in the Indian subcontinent also aligns with notions of purity and pollution. The stigma around doing work that involves impurities (hair, carcass, blood, waste, etc.) is the standard explanation. In the Islamic setting, the concept of najis is used as a parallel to this idea. The issue with such readings is that a doctor who deals with blood or a fashion designer who manipulates tanning right from its early production never faces similar stigma as faced by the barber or tanner. As goes with histories of concepts, contempt and labour are two categories that help us think through a range of questions around the social. Are they universal terms or do specificities have a lot more to offer? Have we always thought of them, while separate and connected, in the same manner since time immemorial? What is contempt? Is it a feeling, sensibility, or disposition? How do people learn contempt? What is labour? How did we come to value/devalue particular forms of labour? These are not random questions but few that provoke an enquiry into the very modes and means by which these concepts have come to be what they are in the contemporary.

\section{Making of a Quack}

The Muslim barbers of Malabar administer circumcisions (maarkam or sunnath), bloodletting (hijama), midwifery, parturition, and the first scalp hair removal for new-borns (mudikalayal/mudikalachil), alongside general tonsorial activities. The barber, in many parts of the world, has historically been recognised with the suffix "-surgeon". It was only in the year 1745 that surgeons in Britain officially split from the Company of Barber-Surgeons to form one for themselves. Additionally, Muslim societies in West Asia and Africa are filled with examples of the barber undertaking minor surgeries and roles (Sajdi 2013) quite similar to their Malabar counterparts. Coming closer to our region, the barbers of Tirunelveli in South India claim their primary occupation as that of the village doctor which was reduced to barbers later on (Ragupathy 2006). The same can be found in oral narratives of the barbers of this study who cherish a strong relation with medicinal treatment, and all barber families I engaged with recorded some form of connection to it in the present or past. Two words were frequently used by barbers when conversations revolve around the curative-chikitsa ${ }^{5}$ and hikmath ${ }^{6}$ - conveying treatment and knowledge involved in healing, respectively. To understand this in an immediate setting, let us look into a few instances. The barber's responsibility does not end with the circumcision surgery. Vichuka, one of my barber interlocutors, told me that once the sunnath/maarkam is done, the process of healing begins. The wound is covered with paccha marannu (herbal medicine). While removing the medicine, the penis is washed with lukewarm water in a gentle patting process called thaloduka. In most cases, this is done after three

4 More often, modern anxieties around masculinity have forced such contemptuous jokes to thrive-a topic that needs separate attention.

5 Roots for chikitsa are found in Malayalam and Sanskrit. It stands for both "treatment" and "serving the ill". Most traditional healing practices in the Indian subcontinent make use of variants of chikitsa.

6 Hikmath or hikmah is an Arabic word closely associated with "hakeem" or doctor in the Indo-Arab-Persian cosmopolis. Wisdom, experience, ruling, etc., are various meanings associated with the term. 
days, while in others before. Barbers, along with the larger society that they are part of, see these duties and responsibilities not just as part of their occupation but as imbibed with the religious. This is apparent in the case of pregnancy when the female barber dons the role of the midwife and healing is initiated long before the delivery of the child. Mahw (erasures) are administered to the expectant women. These are usually pinjanamezhuthu (writing in ceramic) or ezhuteel kudikkal (drinking the written) (Arafath 2015). The midwife uses her finger or a stick to trace-write a few verses from the Qur'an or the Nafeesath mala ${ }^{7}$ and this is consumed along with food or directly. Hence, we find that the barber-surgeon need not be from a distant past in the case of Malabar's Muslim barbers. Further, the position of a medical doctor as a professional designate can also be considered in this analysis.

$\mathrm{HK}$, during his afternoon break at the salon, in one of his contemplative moods asks me to think closely around whose profession is more disgusting (kooduthal arappulath) - the doctor or the barber? Both have to deal intimately with the body and are in direct contact with that which is considered impure. Nevertheless, as he goes on to stress, while one of them gains acceptance, dignity and esteem, the other is considered low in value. By inviting us to deliberate which one is more (kooduthal), he provides a framework for disgust (arappu). ${ }^{8}$ Aversion to particular professions, career preferences and occupational trends are based on differential comparisons-one kind of labour in contrast to another. Rather than setting the premise as remuneration, physicality or creativity involved, and various available modern work variables, HK introduces disgust or contempt as the parameter for this comparative framework. The medical profession is then a mere euphemism for work that is disgusting while barbering services are blatant about it. The doctor comes out scoring higher than the barber while placed on this ladder of disgust, and yet it is the latter who faces the brunt of professional devaluation. This challenge to immediate logic is not employed by HK as an offhand opinion. Rather, we can read it as an issue with the sanctimony of purity-pollution binaries. Supposed Islamic mediation vis-à-vis najis (ritually unclean) is also redundant here with doctors facing no recorded fatwa based on their proximity with impurities, while the barber has in the immediate past. ${ }^{9}$ Nonetheless, comparison with doctors allows us to think of labour and contempt in other ways as well.

The emerging nation of India found itself in a conundrum post-independence. On the one side, it had to create an image as benevolent in contrast to its predecessor, while on the other, the nation had to display itself as progressive and up to date with a modern world. All discussions and debates that deal with tradition in opposition to modernity, the shifts that were in place, scientific goals to obtain and the way forward are all emblematic of the diverse range of anxieties and aspirations that went hand in hand during an initial couple of decades after realising the modern dream of a nation. Trying to make a name for itself, India was deeply concerned with number games and new indicators to measure nation-states like birth rate and infant mortality rates. Biopower came to be not a mere tool of state power but the very means of defining its relationship with its citizens (Rose 2001). Many barber families recorded that government health authorities had distributed medical utensils and stainless-steel scissors to midwives, especially in places where doctors could not make inroads. Preventive measures and preventive medicine were integral to the conception of health discourses in modern India. This was tied along with a neo-hygienist discourse that ushered in new sensibilities of cleanliness, sanitation and safety. The state was highly efficient to the extent that, by the 70s, non-state actors took up the task of the hygiene regime. An example is the mass circumcision camps run by the Muslim Education Society, an important educational organisation in Malabar, intending to provide

7 A panegyric sung in the memory of Syeda Nafeesa, a descendant of the Prophet Muhammad.

8 By borrowing from the barber interlocutor's framework, I reiterate that the field is best approached from a grounded perspective.

9 Fatwas are legal opinions. The barber has been categorised as makruh or undesirable in the past. However, I have not come across fatwas for the same-in recorded or oral narratives-prior to the twentieth century. Further, a qadi (judge) gives me the example of fatwas issued in late colonial Malabar that sought to make learning English makruh. This was revoked later on over time, and he says that fatwas change with context. For legal change during the premodern, see (Hallaq 2009, p. 183). On the question of kafa'ah (equivalence in marriage) in the context of Malabar, see (Amir 2018). 
"safe" circumcisions by modern medicinal doctors rather than "traditional" barbers. ${ }^{10}$ Both instances above exhibit that the nation-led discourse around what is healthy and beneficial for its citizens was also accompanied by defining that which is "harmful" and detrimental. I am interested in how the latter is mobilised and co-present with any health-related discussion in post-independent India.

While it seems that midwives paved the way for gynaecologists, and barber-circumcisers for medical surgeons, the process itself was not a swift rupture from earlier practices but one that was gradually finding its ultimate end in constituting the individual. The emergence of such professionals was deeply tied to an Enlightenment rationale with its regional flavour. Upper castes and nationalists throughout the length and breadth of India engaged in hygienist discourses by mobilising modernity and nation to inscribe the language of caste as illegitimate (Pandian 2002). While the language of caste is crucial to speak about South Asia, one has to be wary of the socio-historical reasons that lead to the creation of boundaries between conceptualising caste and religion (Oberoi 1997). Hence, while lower caste groups found it easier to interact with the Islamic tradition in the premodern era, the new nation officially circumscribed caste to a particular religion (Hinduism) and drastically limited these exchanges. This along with the discourses discussed above further widened the gap between Muslims as a whole and lower castes. This can be seen in narratives where the Muslim barber selectively uses idioms of caste while explaining oppression but refuses to identify with Hindu lower castes. ${ }^{11}$ While this complicates inter- and intra-religious exchanges, let us not lose focus that the modern nation and the meta-narrative of caste are closely entwined into each other (Aloysius 1997). Thus, hygienist discourses that mobilise modernity are not only about inscribing the language of caste as illegitimate but need to be read as one of how modern contempt itself is mobilised and legitimised.

Let us now examine the process of mobilising contempt in an everyday setting. In a conversation with a Muslim post-doctoral candidate from Kerala married to a medical doctor, I asked about the significance of the female barber in parturition and postnatal activities. Not only was the response frantically reproachful, but the post-doctoral candidate went on to malign them as quacks. Basing his claim on how the barber could not determine instances where the foetus gets tangled in the umbilical cord, he made a case for medical practitioners by suggesting the latter to be a safer option. ${ }^{12}$ My interest is in the particular utterance-quack-in the above conversation. The stress on the term, the exasperation to arrive at the comparative point, and the repeated belittling need to be read as the working of contempt at the micro-level. The discussant is part of a neoliberal regime that develops specialisations to meet the requirements of an ever-growing capitalist world. While the argument made by the discussant takes biopower to the site of the individual, it is implemented by reinforcing the state's power in excluding ambiguous occupations and defining specific professions. We find that validation and emergence of the professional are then possible only when contempt is mobilised. Rather than seeing the shift as a "distillation of professionalism out of quackery" (Porter 1985), the rise of the medical doctor is concomitant with the making of the quack in South Asia. Right from state enacted policies to non-governmental endeavours and individual attitudes, mobilising contempt becomes a rallying point for diminishing the status of the barber. The barber-surgeon loses her/his suffix to become a barber-only category. Any other endeavour on their part that moves away from those defined by the neoliberal regime is seen with suspicion and considered as inauthentic and hazardous.

10 I am thankful to the historian Kadavanad Mohamed for this useful information.

11 Ambiguity between caste and caste-like becomes evident in these narratives. I have come across barbers who used the term jathiyetha (casteism) to speak of their condition but would restrain from self-identifying with the term "Dalit" or "Harijan". For an instance from the pre-independent, see the next section.

12 Barbers and midwives have often told me that they undertake only instances that they are sure will lead to normal deliveries. By closely inspecting and feeling around the carrying mother's body and womb, the midwife can sense the position of the foetus and, in some cases, even assist in changing it. For more on traditional maternal care in Malabar, please see Marva (2018). The barber's role continues to this day and it is quite commonplace for them to suggest home remedies and solutions to common medical predicaments to this day. They are also the go-to person for advice when it comes to issues as diverse as marital to health. 
Having thus observed the deterioration of a group of people in the modern nation-state, we are now left to think of ways in which this came about in the intra-religious space.

\section{Reforming the Beard}

Religious reforms set the tone for the eighteenth and following centuries in South Asia. It has generally been accepted as a move to the modern that surpasses earlier "traditional" ills and inequalities. The progressive element is accentuated to display indigenous critical thinking and conceptualise the way forward. But can these ruptures and ingenuity represent the depth of social exchanges that took place under the aegis of the Islamic tradition? The site of the legal, for instance, was rapidly coming to be a distant one from previous settings. I introduce an instance from the beginning of the previous century, a rare document, that revolves around the Malabar Muslim barber. By doing so, the intention was to open up ways in which authority legitimates contempt during this transitionary phase between the colonial and postcolonial periods. The document we discuss is a pamphlet in Malayalam titled "Thadi Purushamodi" or "Beard: Magnificent Masculinity" (Thangal 2012, pp. 477-78) written by the Muslim reformer Sanaullah Makti Thangal (1847-1912) from Malabar. Thangal shares a personal narrative that highlights an intervention in a local dispute. The actors involved are a Muslim barber, a young scholar, ${ }^{13}$ and Makthi Thangal. The barber approaches the reformer following an abusive verbal exchange between himself and the scholar. The latter is accused of slander for having derogatorily called the barber a "low caste hairdresser" (Ambattan) and "one who shaves women's pubes" (pennindeth kalayunnavan). ${ }^{14}$ Without any sign of remorse, the scholar challenges these allegations that Makti Thangal quotes at length:

"I have spoken in two ways and believe it is not wrong. Tending to the beard of Muslims is commonplace. This makes the regular Ossan (Muslim barber) a person who shapes the beard, while he who shaves is an Ambattan (low-caste barber). So, I called him an Ambattan. Second, the beard differentiates man from a woman. When the beard is discarded, it transforms man into a woman. Further, he [Muslim barber] doesn't differentiate between pubic and facial hair. Thus, I testify against his karuthu (moral strength) and pravarthi (practical conduct) that he shaves a woman's pubes. Thangal, punish me if I have committed a mistake." (translation is mine) (Thangal 2012, p. 478)

Makti Thangal goes on to agree with the scholar wholeheartedly and calls forth the ummah (community) to respond to the wishes of God and Prophet Muhammad. This incident and the specific quote require unpacking. To begin with, the pamphlet issued by Makti Thangal is a public one, presented as a personal narrative, that takes off from his lived experience. The barber initiates a complaint, the scholar challenges the accusation, and both seek Thangal's assistance in settling the matter. The narrative structure is similar to a legal one where the barber enacts the plaintiff, the scholar is the defendant, while Makti Thangal dons the role of the judge. The pamphlet hardly finds the barber's voice but goes on to quote the scholar in verbatim. The scholar defends his case by rationalising that since the Muslim barber had picked the job (shaving beards) of a lower caste, the roles themselves had been reversed. The background here is that Muslims consider maintaining and tending to the beard as part of their tradition. While the Muslim barber is known to shape and tend to men's beards, the low-caste Hindu barber is known to shave it off completely. Hence, the scholar alludes to a swap in signifiers for rhetorical effect-the Ossan becomes an Ambattan and vice versa. Not stopping there, he goes on to attack the barber's masculine honour and dignity by declaring that the barber shaves the woman's pubic region. He arrives at this conclusion by suggesting that the

13 It is not sure whether the scholar is a religious one or not. It is possible, given the context being Kochi market, and the use of "kochu-vidhvan" suggests that he is a modern man, influenced by reformist trends, slightly knowledgeable in religion.

14 Literal translation does not imply the pubes, but the next few sentences uttered by the scholar makes it clear: “... murattilullathum mukhatullathum onnanu...". 
Muslim barber, in his path to moral degeneration, had lost comprehension in distinguishing between men and women. The labour that the barber takes up comes under severe criticism from the scholar and this can be seen once he moves away from his long rhetoric. The scholar is interested in pointing out the errors of the barber. The means (abuse) is questionable, but we get a sense of the position of the Muslim barber in light of other barbers from an emic perspective. Finally, Makti Thangal's affirmation of the scholar and clearing him of all charges is done by invoking God and the Prophet thus setting the verdict as an example for the larger Muslim community (ummah) to follow.

For analysis, I drew inspiration from works that dealt with Shari'a and Islamic legality by closely reading law as procedure and uncovering textual habitus vis-à-vis legal cases (Messick 2018) and those that analyse the moral-social life of Shari'a in premodern times (Hallaq 2009). The pamphlet serves as a gateway into a world that is fast changing. The social, legal and moral are all played out and contested, while concepts like contempt and labour are shaped and given direction. The three actors and the larger Muslim society, in the above instance and era, are not unaccustomed to the workings of premodern Shari'a. Mediation and arbitration in disputes were part of everyday processes and people had access to both official and unofficial means for the same. Finding an arbiter was the easier option and going to the qadi's (judge's) court was seen as a final option (Hallaq 2009, p. 163). We find that the same is in place in our case. The enacting of the specific roles-plaintiff, defendant and arbiter/judge-by all three proves the point. They know exactly who has to open the case, who needs to respond and to whom they should turn for a settlement or solution. The role of the accuser is also set, as he is the one who is responsible to prove accusations. Further, the barber approaches Thangal to lodge a complaint with the belief that the slandering against him will be revoked. He seeks justice ('adl) and is aware of his customary safeguarding (samrakshanam), a point I will return to in the next section. This goes along with "social underdogs" who knew the workings of the court and intricate legal points before approaching an arbiter or the court (Hallaq 2009, p. 172). Moreover, "total loss" was avoided in most cases with the wrongdoer allowed partial recovery, and this was a measure to preserve social order and harmony (Hallaq 2009, p. 164). However, Makti Thangal takes a drastic step away from usual Shari'a conventions and not only gives a verdict against the underdog but also assures no relief to the plaintiff. The religious scholar, on the other hand, seems to still retain the moral idioms of Shari'a when he finally moves away from rhetoric to make his main argument-the barber's practical conduct (pravarthi) was not in correspondence with his moral strength (karuthu). By shaving instead of shaping the beard, he had laid himself and his occupation in danger of being corrupted socially (reduced to an Ambattan) and morally (compared to pennindeth kalayunavan).

Makti Thangal utilises this pamphlet to multiple benefits. By disclosing and allowing public consumption of the events of a private dispute, he proclaims his authority as an arbitrator in society. Moreover, this position enables him to direct contempt by highlighting the entire dispute rather than the central argument alone. We find that easy conceptualisation of reform as a simple switch from one set of practices and ideas to another is not the case. Rather than mobilising the modern by suggesting colonial law or modern legal idioms, we find Makti Thangal vying for a place in the tradition. First, he seeks recognition from the scholar by affirming the defence. Second, the scholar acts as a trope to display Makti Thangal's good standing (or perhaps higher standing) among the Muslims of Malabar. Next, he posits himself as an alternative to judges and arbiters, especially those prevailing and wielding power in the community like the qadi (judge) and the mufti (legal expert).

However, unlike the scholar, Makti Thangal is not interested in the moral strength or practical conduct of the barber. This is evident in the titling of the pamphlet which is to do with beard and masculinity. He builds on ideas around honour, dignity and piety to reach a larger audience. Almost similar to setting a legal maxim, the caption and conclusion direct the reader to the significance of the beard in a Muslim man's life. It should not be shaved and doing so would make him effeminate. While the scholar's reversal of signifiers-Hindu barber (Ambattan) and Muslim barber (Ossan)—is aimed at the individual, Makti Thangal appears to extend the analogy to display the beard as that which distinguishes Muslims from non-Muslims. At once, the beard becomes not only a symbol of 
piety but also one of identity that honourable Muslim men are obliged to maintain. Such formations of identity, defining its boundaries, invoking gender and religious differences and inflating particular symbols are symptomatic of the modern. Such imaginings of the beard as representative of the whole "ummah" (Islamic community) is also a distinct cry for the merging of symbols and the political. Makti Thangal was a staunch champion of inter-religious debates and often debated with missionaries. Whether such rhetorical endeavours led to his conception of Islam and other religions is arguable, but it does give the impression that his category of the Muslim did not necessarily include the hairdresser. The barber and his occupation are hardly Thangal's concerns. They are reduced to a filler status, rendered voiceless and partake the scene only to enhance the scholar and Makti Thangal. The scholar's purpose is also not completely met. If he aimed to seek moral retribution and bring the barber back to his earlier position (morally and socially) by chastising, then Makti Thangal has also failed the scholar. Moreover, by disrupting the image of the Muslim that Thangal has been casting intently, the barber is closer to his non-Muslim counterpart. Karuthu and pravarthi were to move away from centre stage and make way for the political.

\section{The Barber's Callus}

As part of fieldwork, a large number of respondents related their circumcision (sunnath or maarkam) accounts to me in detail. With time, I realised that these narratives had amassed to transform into an archive that I now call the "Sunnath archives". Circumcisions in Malabar constitute an important event in the life of a Muslim. It is usually celebrated grandly and, hence, the addition of kalyanam (marriage). A goat or cow is sacrificed, and a feast accompanies the ritual. Young boys, to be circumcised, between the ages of four and seven, ${ }^{15}$ wear white or new clothes. Vichuka, at Darshana Salon, who has administered numerous circumcisions over the past two decades, told me that sunnath should be done when the child can remember and should be told that he is going to be circumcised. Memory is crucial to the experience and almost all sunnath qissakal (circumcision tales) I came across, written or oral, would begin with pain. I have often seen people wince when they think of this personal yet social event. Muslims from different walks of life shared their anxiety, pain and jokes around circumcision, which can be seen in other contexts as well (Mehta 1996). The barber and his tools regularly feature in most narratives within the Sunnath archives. ${ }^{16}$ The image of the barber from memory, by and large, is a stern one and his blade or knife generally makes an appearance.

However, like any archive, our Sunnath archives also reflect the particular ways in which people remember, and, in that remembrance, inadvertently neglects, excludes and defines the insignificant. Among these sunnath qissakal, almost hidden in the margins, few narratives stand out from the rest. These are barber's accounts on tools and bodies. For instance, I learn from HK that some expert barbers, in the earlier generation, would go on to use the Ossa kathi (barber's knife/blade) on their body. Barbering, performed sitting before the advent of the modern barbershop, saw the barber relaxed on the steps by the palli kulam (mosque pond) with his leg stretched. He would often use the blade or knife against his shin to clean the Ossa kathi. This friction between the blade and skin would often, over time, form into a callus (thazhamb). Quite coincidentally after telling me about these unique calluses, HK, the same barber who gave us a comparative method between barbers and doctors in an earlier section, takes an about-turn to find similarities among the two professions. He states that the doctor's work is based on the tools they use, highly similar to a barber. He joins the two to then compare them with a further set of occupations-fishermen and farmers-who rely on the strength of their bodies. This, according to HK, reflects their nature and work. This move to set the indicator for life and labour as one around tools and bodily strength is important here. Further, from the preceding

15 It is common to wait until these ages to circumcise. However, the trend in Malabar is leaning towards early circumcisions, right from the first month after the birth of a boy, through medical surgery.

16 The archives also tend to show a negative trend in mentioning the barbers as we move to more recent generations. The doctor seems to have displaced the barber in this regard. 
narrative on calluses, we can extend HK's idea to suggest that tools are extensions of bodies and vice versa.

The Sunnath archives present us with a peculiar case. Not a single non-barber respondent, across age groups, was able to recollect the barber's callus. This comes as an afterthought to the multiple comments on the barber's tools and dispositions. How does one think around this selective amnesia? What relevance can calluses have in a world that has been shaping bodies according to the demands of a neoliberal power structure? Let us think of the callus itself and then move to another set of popular calluses, the prayer bump. Calluses are hardened skin or the thickening of the skin due to the fact of friction. It partially resembles a scab but turns out to be a permanent one. The idea of contempt is possible when we think of how the Arabic term qaraf could mean a bark, disgust and/or a scab. ${ }^{17}$ However, these are temporary, and the process signifies healing or a change in the state of affairs, to an extent. Prayer bumps, or zabiba (literal raisin), are well recognised in the Muslim world. ${ }^{18}$ They appear primarily on the forehead, and occasionally around the ankle and foot. The former, more apparent, denotes a pious Muslim. These are calluses formed by friction between the forehead and the prayer mat during prolonged prostration (sajadah) in prayer. It has been contested and debated, with the larger Muslim community divided on what kind of piety does it imply. Some take the opinion that it is genuine, while others say that it can be avoided by cautious exertion and the use of softer material for prayer mats. The latter implicitly suggests that piety for such people is dubious. ${ }^{19}$ While the debate might take various twists and turns, I am interested in the very inception of the zabiba as worthy of debate and discussion. Within the range of sources I have had access to, the prayer raisin does not occur in relation to piety prior to modernity even once. ${ }^{20}$ When it does finally show up in the contemporary, it styles itself like a pious identity. ${ }^{21}$

In opposition to the marginal barber's callus, the prayer raisin finds itself within a thriving discourse around piety. Similar to the pain and other experiences that the modern Muslim remembers, the prayer bump is an easily recognisable and mentionable callus unlike the barber's. Following the pamphlet set in the previous section, we find that if moral strength and practical conduct conflicted earlier, the contemporary shows a complete opposition among the two. The barber's work is recognised only to speak and remember the experiences of the self. The barber, himself or herself, does not point to any scope for recognition. Their actions seem to have nothing to do with the ethical in this setting. I would now like to invoke another possibility of the callus-that of accumulation. ${ }^{22}$ I will focus on the barber's callus given its unblemished nature in comparison to the heavily contested modern prayer bump. ${ }^{23}$ The callus is hardened skin but is also an accumulation of the epidermis. The presence of the barber's account and callus in the Sunnath archives is not a pedantic endeavour but one that tries to read the archive in more ways than one. The intention is not to read against the archive (Stoler 2010) but to see how this vital margin provides a way to think through concepts like work and ethics. The barber's callus, when compared to its twin, the prayer bump, does not immediately call forth the pious in the modern Muslim imaginary. I would like to push this image to other calluses that can be found in the Islamic tradition. Within the Prophetic tradition, there is a Hadith where on returning from the Ghazwa of Tabuk, the Prophet shook Saad bin Mu'ath's hands and said, "What has made your hands so rough?" implying the hardening of the palms [calluses or in

17 Fourteenth-century Arabic dictionary, Lisan Al Arab, by ibn Manzur.

18 In Salman Rushdie's novel Shame, the prayer bump is known as a "bruise of devotion" (Rushdie 1983, p. 98).

19 For a case in Egypt, see https://www.nytimes.com/2007/12/18/world/africa/18egypt.html (last accessed on 30 August 2019).

20 The closest was a Hadith (Prophetic tradition) that states that a pious man can be recognised by his face. This does not imply the prayer bump and can go on to mean anything as varied as humility, humbleness, nūr, glow, shine, etc.

21 My favourite example is from The Vicks Mango Tree (Salim 2012). The author, Anees Salim from Kerala, beautifully weaves a narrative around a Muslim protagonist who has to prove his piety since he does not have a prayer bump. He is then forced to show his circumcised penis.

22 I am thankful to Shagufta Kaur for this suggestion.

23 I am not suggesting that the barber's callus is not modern or premodern. I am merely suggesting that the barber's callus can provide us with an alternative perspective that could span between the modern and premodern. 
the process of becoming one]. Saad replied: "Oh Messenger of Allah, I work with the hoe and the plough to provide for my family." The Prophet went on to kiss his hand and said, "This is a hand that will never touch hellfire" and in another narration "These are hands that are loved by Allah and His Prophet" ${ }^{24}$ Good conduct-ranging from work, actions and deeds-and belief in the Islamic tradition are strongly linked to one another (Izutsu 2002, pp. 204-7). Similar is the Prophetic saying that can be found in "al kaasib habib Allah" or the "one who earns is dear to Allah". This idea, that one who earns a rightful living by working hard is close to God, indicates piety can be found in multiple ways, and earning an honest livelihood is part of it. The barber's callus, without doubt, proves the hard worker. How long before we realise the connections between one's karuthu and pravarthi?

I will end this section with a short ethnographic vignette in the hope that the conversation between moral strength and practical action can still perhaps be captured in the contemporary:

“It is New Year's Day and a Sunday. Business looks bleak at Darshana Salon with the opening of many new barbershops in the vicinity. I think aloud strategies to gain more returns. "How about putting up photographs of our freak customers on the wall?" 25 I suggest to Riyas. We were standing outside the salon opposite an empty juice shop that was doing worse. "Earlier, there used to be photographs of models," he replies. "But, then I took them off because I learnt it was un-Islamic." He gently smiles and adds, "Padachon therumne (the Creator will provide)." At that very moment, as if by divine intervention, a sizeable group of freaks, who had come to attend an event close by, entered the juice shop. Surprised, Riyas and I look at each other. He was smiling with his eyes this time."

\section{In Service of the Sufi}

We have seen the various ways in which contempt is negotiated in the domains of labour, work and occupation. While contempt has been mobilised and directed, in colonial and post-independent eras, to exclude some and enhance others, there is also a potential of redirecting contempt-which in parenthesis "(re)" suggests an in-betweenness in the realm of the ethical. Let us begin with two contradictory narratives from the field around patronage and rights to initiate this discussion. While discussing the past and present of the barber with elite sections of the Muslim community in Malabar, they would often appeal to a rights-based discourse to talk about a legacy of patronage. Avakashangal (rights) is a heavily loaded term that resonates well in present-day Kerala. The southern state of India has seen numerous struggles that have voiced and benefited through the modern discourse of rights-human, liberal, land, worker, Dalit, tribal and minority to name a few. My privileged respondents spoke of nātu maryada (local custom), sthanangal (position) and avarude avakashangal (their rights) while discussing the barber's social condition. Some would allude to the importance of the barber in rituals like circumcision and festivals like the wedding, while others would talk about how certain barbers were attached to particular families. Patronage is given a beneficial angle, and the discourse around rights are given continuity from an earlier patron-client relationship. Criticisms for this are obvious and rather than entering those, I will try to posit the barber's understanding of patronage. Rather than the various terms used by local elites, the barber uses the concept of samrakshanam (customary safeguarding) to discuss their relationship with the larger locality they are placed in. This idea of protection or security needs to be contextualised. Hamza, who runs a single-chaired, nameless barbershop, illuminates upon the same:

24 This Hadith is a popular one and has been criticised as inauthentic. See al Suyuti's The Created Pearls on Fabricated Hadiths. However, it goes on to prove that these idioms and concepts were quite common among people. In the Islamic tradition, hadith are the chains of transmission of the Prophetic Sunnah that have gained an authoritative status after the death of the Prophet (at least three centuries later). For a detailed discussion see Hallaq (2009).

25 "Freak" is the modern lingo in Malabar that denotes fashionable hairstyle and attitude among youth. The quintessential hairdo of a "freak" is the long, raised hair. At times, they are referred as punk as well. My strategy was to ensure customers returned to Darshana by targeting the largest crowd available-youngsters. 
"Earlier there was a relationship of samrakshanam (protection/customary safeguarding). Every village would have a barber. People would address them as 'nammude Ossan' (our barber). This meant many things, but the most important one was that of employability and occupational security." I am reminded of Hamza's example where he had once narrated that a group of people on boats, who had come to his town, had their own barber. Correspondingly, he adds, "many decline invitations to be tended by barbers who do not belong to their village." Hamza finds an analogy for this relationship in an old story (Aesop's?) he had learnt in school-the lion and the mouse. Accordingly, the lion allows the mouse to pass by saying that the former can do so because the lion has willed no harm on the mouse. The mouse replies that even though he is small, he can be of use to the lion, some day. And sure enough, there comes a situation where the lion is trapped in a hunter's net. The tiny mouse makes use of his sharp teeth and nibbles into the trap to set the mighty, now humbled, lion free."

The story of the lion and the mouse, or the divergent use of terms away from one that builds on the modern right's discourse, is not drawn upon over here to present a picture of resistance or even as a counternarrative. I never asked Hamza or other barbers what a "response" to an elite would be around patronage and rights. Also, he merely stated the story without referring to who the lion and mouse were. ${ }^{26}$ An easy answer that the barber is the mouse and the larger society is the lion-that the former or a tiny being can also be of great value-is tempting as an analysis. Let us not jump to conclusions for now and continue with this idea of samrakshanam. I was able to find the oldest recorded mention of Malabar's Muslim barber in a theological source that is part of the ordinary and every day. ${ }^{27}$ In Fatahul Mueen, the standard figh (Islamic jurisprudence) text in Malabar since the sixteenth century, by Makhdum II (2018, pp. 388-89), in the Book of Gifts (Bab fil Hiba), a section that deals with custom ('urf), we find that the barber-surgeon (al halliq aw al khaatin) is addressed quite respectfully as "khadimu sufih" - the one in service of the Sufi or the one on the path of Sufism. ${ }^{28}$ The discussion is on gifts received after circumcision and the grand jurist opines that they are rightfully the barber's unless the barber decides to give it away. He makes this position official by pronouncing that there is no doubt (gaze) in custom and that "it is set". I believe Hamza's idea of samrakshanam is not one that builds on patronage in the feudal sense of mutuality, nor does he use the dictums of modern rights. I humbly suggest that traces or remnants of an ethical pattern can be discerned here. The fiqh is strongly versed with the idea of protecting the Sufi-barber-surgeon from the clutches of possible misinterpretations of local custom. Such customary safeguarding is not merely ensured but the tone is severe, almost suggesting contempt at those who would try to deceive the selfless barber. Recent studies, notably Shabana (2010), have complicated the notion that Islamic law and local customs are at loggerheads. Rather, they imbibe from each other, set the tone for the social and ethical, and an organic dialogue between the two ensures constructive change over time. Contempt, then, as a concept can also be said to have ethical vestiges.

The claim seems drastically premodern, abstract and set against social reality and praxis. The difference in years affects even conceiving the same in the present. Taking a radical step from perpetual standpoints in moral philosophy, quite recently, Bell (2013) calls for an "ethic of contempt" in the face of "vices of superiority". She reverses the usual understanding of contempt to engage with a more positive sense of the term. While acknowledging and being sensitive to kinds of contempt that are used to stigmatise vulnerable people, she also unlocks the concept to other potential

26 Nor did I think it was necessary to follow this with a question and obsess around "knowing" as an anthropologist. Rather than directing or redirecting the course of our conversation, I believe the interlocutor is best placed to do so. As an ethnographer, my duty is to listen.

27 I have come across Malayalam translations and extensive commentaries of the Fatahul Mueen in most households, placed right next to the Qur'an or in showcases. It is picked up now and then to clear doubts regarding various facets of daily practices-be they ibadat (structured obedience) or mu'amalat (transactions).

28 It is the oldest direct reference to the barber-surgeon that I could find in Malabar. Further, it is also the only place Makhdum II directly talks about tasawwuf (Sufism) in this Fiqh manual. 
meanings. Beyond serving as a form of protest, contempt also opens us to the knowledge of the world and acts as an important moral motivation (Bell 2013, p. 52). Let us consider a closer setting from our study. This can be glimpsed through the following episode I share here from my field notes:

"During a Nurisha tareeqat session ${ }^{29}$ by Sheikh Moideen Musliyar in a small makeshift khanqah ${ }^{30}$ on the beachside, the Sheikh compares himself to an Ossan (barber) in front of a packed audience. He proceeds to say that one goes to the barbershop and subjects his head to the barber's numerous twists and tilts to look beautiful. After a few weeks, the person re-grows his hair and requires beautifying again. Identical to the barber, the Sheikh informs that he engages with his mureed (follower). He would spot individuals' ills and issues, not to belittle, but to make them beautiful. People needed to realise they had to be in the presence of the Sheikh, now and then, to purge their ill-doings and problems."

In a change of scenario, the Sheikh not only uses the barber as an analogy, but is interested in replicating the latter's labour, technique and presenting an ethical picture that can find a connect with the audience. Further, he suggests that human beings are prone to moral inadequacies and they need not worry when the Sheikh scorns on their actions. Contempt is employed as a tool, in this barber-instructor analogy, to guide followers to a better path.

\section{Conclusions}

This article aimed to look at the various ways in which a category of power like contempt has been conceptualised in the past (and in many ways extends to the present). The diverse meanings of contempt reflect how authority has transformed ideas around labour and piety. This authority in itself is not completely defined though degrees of power can be seen to vary. However, possibilities are available within the realm of the ethical, an area often not dealt with, and we are yet to discern the nature of the same. We began the article by introducing a method from the field to suggest ways in which we can open our discussion on contempt and labour. The differential valuing of the doctor and the barber make possible comparisons that force us to think of the socio-historical conditions that allow for such wide disparities between the two professions. The contemporary discourse of hygiene couched in terms of caste defines the modern nation. Biopower showcases the state's inherent nature to manipulate, control and determine what deserves contempt and what then needs to be excluded. The peculiar nature of the barber-one where she/he is capable of various kinds of work-challenges a neoliberal regime that develops specialisations to meet the demands of the capitalist world. Here, the quack comes into existence rather than having always been available. The emergence of the professional is possible only with the making of the quack. We then went back in linear time to locate contempt and labour around the barber during the peak of colonialism in South Asia. We found that the split between morality and conduct was further given a blow with reformers directing their attention to the political which was further defined and limited to identity. What might have been an organically assimilative practice of beard-keeping and relationship with calluses, in the Islamic tradition, takes on a (partial or complete) sedimentary representative or/and communicative mode in contemporary Malabar. By tracing how the beard and the callus were conceived before such concretisation, the attempt was to open discussions around overlapping domains of morality and praxis. We went on to read the Sunnath archives to observe how people selectively remember. The barber's callus in contrast to the prayer bump is capable of invoking other ways of being pious. This helps complicate and redirect our attention back to moral strength and practical conduct. Finally, by following the Muslim barber of Malabar to his earliest available written source, we found contradictions between rights-based modern

29 From turuq or Sufi order. These are usually dhikr majlis where chanting and preaching take place. People can directly communicate with the Sheikh and tell him about their problems. Women participate in large numbers.

30 Usually translated as Sufi hospice. However, this was not a full-fledged one. It had many mats, a tin roof and was only functional on Thursday nights. 
discourse and customary safeguarding. In this, there is a reversal of value for contempt and we find that it can also act as an important source of moral motivation.

In perhaps the most important anthropological study involving caste and Islam, in this century, Lee (2018) unsettles the recurrent trope of descent-based genealogy (nasl) to posit the ethical. By closely studying the Halalkhor, a group of Dalit Muslims involved in sanitation work, he works through various origin narratives to highlight both piety and the dignity of labour. He moves from "intimate untouchability" to "intimate touchability" to set the ground for Islamic ethics of care. While he successfully traces shifts in history and the devaluation and shrinking of the Halalkhor, his take on the conditions of the modern itself is hardly explicit. This is best seen when he avoids defining Islamic ethics. Which again is fine, after all definitions do limit any phenomena. However, he ends up drawing an idea of what ought to be Islamic ethics when he subtly compares how the Halalkhor makes use of Islamic tropes and how dominant castes do. The problem we have at hand is a question of continuity of Islamic ethics from the premodern to the modern. For the staunch critic of modernity, the very facets of premodern Islam are incompatible with the modern project that builds on the separation of Is and Ought (Hallaq 2013). The ethical turn in studies around Islam and South Asia is important and around the corner. The present as a standalone temporal framework is not going to help make sense of it. Rather than pointing to one kind of ethics as an alternative to the other, the attempt in this article was to trace shifts in concepts like contempt and labour. The present allows us to revisit the past in the most unusual of places. Reading them simultaneously permits an approach to histories of disparate categories that are at once sensitive to the effects of modernity, illuminates ruptures and takes the subject's narrative seriously.

Funding: Field research was carried out with an Indian Council of Social Science Research Fellowship (Ministry of Human Resource Development, New Delhi). Further, preliminary drafts of this article were written during a Fulbright-Nehru Doctoral Research Fellowship (Fulbright Board, Washington D. C. and the United States-India Educational Foundation, New Delhi) at Columbia University in the City of New York in Fall 2017 and Spring 2018.

Acknowledgments: The author would like to thank A. R. Venkatachalapathy and Brinkley M. Messick for their supervision; Omar Abdel-Ghaffar, Shirin K.M., Mubashir Hameed, Muhammed Niyas Ashraf, Muhammed Aslam E.S., and Abdul Rahiman U.P. for their support and comments on earlier versions of this article. The author would also like to thank the anonymous reviewers for their valuable insights.

Conflicts of Interest: The author declares no conflict of interest.

\section{References}

Ahmad, Imtiaz. 1967. The Ashraf and Ajlaf Categories in Indo-Muslim Society. Economic and Political Weekly 2: 887-91.

Aloysius, G. 1997. Nationalism without a Nation in India. New Delhi: Oxford University Press.

Amir, Safwan. 2018. Accusing Islam of Casteism in the Name of Kafâà Is Misconceptualized. Interview in Al-Irshad. Kasargod: Darul Irshad Academy Prasidhikeranam.

Arafath, Yasser. 2015. Saints, Serpents, and Terrifying Goddesses: Fertility Culture on the Malabar Coast (c. 1500-1800). In Histories of Medicine in the Indian Ocean World. Edited by Anna Elizebeth Winterbottom and Facil Tesfaye. New York: Palgrave, pp. 99-124.

Bell, Macalester. 2013. Hard Feelings: The Moral Psychology of Contempt. New York: Oxford University Press.

D'Souza, Victor S. 1959. Social Organization and Marriage Customs of the Moplahs on the South-West Coast of India. Anthropos 54: 487-516.

D'Souza, Victor S. 1973. Status groups among the Moplahs on the South-West coast of India. In Caste and Social Stratification among Muslims in India. Edited by Imtiaz Ahmad. New Delhi: Manohar Publications.

Ekman, Paul, and Karl Heider. 1988. The Universality of a Contempt Expression: A Replication. Motivation and Emotion 12: 303-8. [CrossRef]

Fanselow, Frank. 1996. The disinvention of caste among Tamil Muslims. In Caste Today. Edited by C.J. Fuller. Oxford: Oxford University Press.

Hallaq, Wael. 2009. Sharī'a: Theory, Practice, Transformations. Cambridge: Cambridge University Press. 
Hallaq, Wael. 2013. The Impossible State: Islam, Politics, and Modernity's Moral Predicament. New York: Columbia University Press.

Izutsu, Toshihiko. 2002. Ethico-Religious Concepts in the Qur'an. Montreal: McGill-Queen's University Press.

Kasim, Muhammadali P. 2018. Mappila Muslim Masculinities: A History of Contemporary Abjectification. Men and Masculinities. [CrossRef]

Kunju, Ibrahim A. P. 1989. Mappila Muslims of Kerala-Their History and Culture. Chennai: Sandhya Publications.

Lee, Joel. 2018. Who is the true Halalkhor? Genealogy and ethics in Dalit Muslim oral traditions. Contributions to Indian Sociology 52: 1-27. [CrossRef]

Makhdum II, Shaykh Zainuddin. 2018. Fatahul Mueen bi Sharh Qurratul 'Ayn bi Himaatul Dheen. Calicut: Al Asas Publication.

Marva, M. 2018. Traditional Maternity Carers of Malabar: Caste, Religion and Knowledge. Ala (Issue 4). Available online: http://ala.keralascholars.org/issues/4/maternity-carers-of-malabar/ (accessed on 30 August 2019).

McGilvray, Dennis B. 2008. Crucible of Conflict: Tamil and Muslim Society on the East Coast of Sri Lanka. Durham: Duke University Press.

Mehta, Deepak. 1996. Circumcision, body and community. Contributions to Indian Sociology 30: 215-43. [CrossRef]

Messick, Brinkley. 2018. Shari'a Scripts: A Historical Anthropology. New York: Columbia University Press.

Miller, Roland. 1976. Mappila Muslims of Kerala-A Study in Islamic Trends. Hyderabad: Orient Longman.

Muneer, Aram Kuzhiyan. 2016. Poetics of Piety: Genre, Self-Fashioning, and the Mappila Lifescape. Journal of the Royal Asiatic Society 26: 423-41.

Nazir, Pervaiz. 1993. Social Structure, Ideology and Language: Caste among Muslims. Economic and Political Weekly 28: 2897-900.

Oberoi, Harjot. 1997. The Construction of Religious Boundaries: Culture, Identity, and Diversity in the Sikh Tradition. Oxford: Oxford University Press.

Pandian, M. S. S. 2002. One Step Outside Modernity: Caste, Identity Politics and Public Sphere. Economic and Political Weekly 37: 1735-41.

Porter, Roy. 1985. The Patient's View: Doing Medical History from below. Theory and Society 14: 175-98. [CrossRef] [PubMed]

Punathil, Salah. 2013. Kerala Muslims and shifting notions of religion in the public sphere. South Asia Research 33: 1-20. [CrossRef]

Ragupathy, Ko. 2006. Adi Maruthuvar: Savara Thozhil Arakkapatta Varalaru (Traditional Doctors: The History of Becoming Barber). Pondicherry: Vallinam Publications.

Rose, Nikolas. 2001. The Politics of Life Itself. Theory, Culture, $\mathcal{E}$ Society 18: 1-30.

Rushdie, Salman. 1983. Shame. London: Vintage.

Sajdi, Dana. 2013. The Barber of Damascus: Nouveau Literacy in the Eighteenth-Century Ottoman Levant. Palo Alto: Stanford University Press.

Salim, Anees. 2012. The Vicks Mango Tree. New Delhi: HarperCollins Publishers India.

Shabana, Ayman. 2010. Custom in Islamic Law and Legal Theory: The Development of the Concepts of 'Urf and 'Adah in the Islamic Legal Tradition. New York: Palgrave Macmillan.

Stoler, Ann Laura. 2010. Along the Archival Grain: Epistemic Anxieties and Colonial Common Sense. Princeton: Princeton University Press.

Thangal, Makti. 2012. Makti Thangalude Sampoorna Krithikal, 2nd ed. Calicut: Vachanam Books.

Tschacher, Torsten. 2014. The Challenges of Diversity: 'Casting' Muslim Communities in South India. In Being Muslim in South Asia: Diversity and Daily Life. Oxford: Oxford Publications.

(C) 2019 by the author. Licensee MDPI, Basel, Switzerland. This article is an open access article distributed under the terms and conditions of the Creative Commons Attribution (CC BY) license (http://creativecommons.org/licenses/by/4.0/). 